Katarzyna Szymala

Szkoła Podstawowa, Gimnazjum i Liceum „Strumienie” Stowarzyszenia STERNIK

E-MAIL: kszymala@wp.pl

\title{
Przebaczenie jako działanie. O znaczeniu tego, co nieprzewidywalne dla edukacji
}

\section{STRESZCZENIE}

Celem artykułu jest zwrócenie uwagi na przebaczenie w aspekcie jego nieprzewidywalności (asystemowości) oraz zasygnalizowanie znaczenia tej kategorii dla edukacji i kształcenia nauczycieli. W tekście zostaje także ukazana możliwość praktycznego przeniesienia tej kategorii na grunt funkcjonowania szkoły jako instytucji, zgodnie ze znaczeniem, jakie nadaje przebaczeniu Hannah Arendt.

SŁOWA KLUCzOWE: przebaczenie, działanie edukacyjne, nieprzewidywalność, szkoła jako instytucja, humanistyczna orientacja edukacji, kształcenie nauczycieli.

\section{Wstęp}

Urynkowienie edukacji i poddanie jej logice konkurencyjności jest w zasadzie uznawane dzisiaj przez badaczy za fakt ${ }^{1}$. Ulokowanie jej w obszarze tego, co spodziewane i przewidywalne oznacza wpisanie kształcenia i wychowania w schemat procesu generującego konkretne, oczekiwane - by nie powiedzieć konieczne wyniki edukacyjne ${ }^{2}$. Rola tak „zaprogramowanej” edukacji ogra-

1 Mam tu na myśli m.in. analizy Tomasza Szkudlarka oraz Eugenii Potulickiej, wielokrotnie przytaczane i komentowane w literaturze przedmiotu. O znaczeniu wartości humanistycznych w szkolnictwie wyższym zob. np. niedawno opublikowany wywiad z dziekanem Wydziału Humanistycznego Uniwersytetu Szczecińskiego, dr hab. Barbarą Kromolicką, Jednoczymy wokót myśli humanistycznej, http://www.przeglad.usz.edu.pl/attachments/article/o/PU_czerwiec2014_internet.pdf [4.11.2014].

2 Zarówno konieczność, jak i nieprzewidywalność są używane w artykule w znaczeniu, jakie przypisuje się tym słowom potocznie i jak funkcjonują w obiegu codziennym. Być może pojęcie konieczności (obok kategorii wolności) niesie ze sobą najwięcej filozoficznych konotacji. Mówi się o koniecznych prawach przyrody, przeciwstawiając je zasadzie nieokreśloności właściwej bytom wolnym. Określenie „konieczny” pojawia się tam, gdzie kontekst i charakter działań wskazują na podległość strukturze, ale też na niepodlegającą dyskusji dyspozycję do zrobienia czegoś. 
nicza się w praktyce do produkowania wyników edukacyjnych33. Oczywiście, wciąż aktualna pozostaje koncepcja kształcenia akcentująca podmiotowy aspekt działania oraz humanistyczne wartości. To ważne, gdyż obszar aksjologii kieruje się inną racjonalnością. Dobra niematerialne, powstałe w trakcie szkolnych interakcji, mają zdecydowanie odmienny status. Łączy je to, że nie można ich poddać logice przewidywalności.

Celem niniejszego artykułu jest przedstawienie refleksji nad znaczeniem przebaczenia dla edukacji, zwłaszcza w aspekcie jego nieprzewidywalności (asystemowości). Wybór tej kategorii nie jest przypadkowy. Jej „nierynkowy” charakter podkreśla znaczenie dóbr niematerialnych w edukacji oraz szkoły jako miejsca praktyki wolności, w którym możliwa jest realizacja działań celowych, choć niedających się zaprogramować przez system. Zajęcie takiej perspektywy pozwala na „rekontekstualizację edukacji”, to znaczy na przeniesienie jej z ekonomicznej do właściwej, humanistycznej, domeny.

Punktem wyjścia do dalszych uwag jest stwierdzenie, że kształcą nas przede wszystkim osoby (edukacja dzieje się między osobami), a dopiero wtórnie instytucje4 . Jeśli rzeczywiście edukacja ma się wyróżniać czymś więcej niż tylko transmisją wiedzy, to o jej szczególnym charakterze mogą stanowić etycznie naznaczone relacje osobowe oraz ujawniające się w tych relacjach wartości: szacunek, życzliwość, autorytet, empatia5.

3 Być może najlepiej ideę sprzeciwu wobec zredukowanej wizji szkoły oddają słowa Bogusława Śliwerskiego: „Szkoła przestaje być szkołą, kiedy staje się codzienną grą o przetrwanie na rynku idei, przedsiębiorstwem poszukującym coraz lepszych strategii dotarcia do bogatych, by zainwestowali w pomnażanie swojego kapitału i spekulowali nim na "giełdzie ludzkich istnień”. Zob. idem, Komu stuża rankingi oświatowe?, [w:] Przestrzeń edukacyjna - dylematy, doświadczenia i oczekiwania społeczne, M. Kowalski, A. Pawlak, A. Famuła-Jurczak (red.), Oficyna Wydawnicza Impuls, Kraków 2010, s. 24.

4 Na ten aspekt kształcenia zwrócił uwagę Piotr Czekierda, prezes Collegium Wratislaviense, podczas wystąpienia na I Ogólnopolskim Kongresie Tutoringu, który odbył się w maju 2014 roku w Warszawie.

5 Ten nurt myślenia o edukacji jest może najbardziej bliski koncepcji tutoringu. Obecnie, w ramach debaty nad kulturą edukacji w szkolnictwie wyższym, próbuje się powrócić do relacji mistrz - uczeń w systemie edukacji publicznej. Zob. np. program I Ogólnopolskiej Konferencji Naukowej - Kultura edukacji szkoły wyższej - różnorodne perspektywy, Białystok 14-15 listopada 2014 roku. Informacja o konferencji została zaczerpnięta z Biuletynu Informacyjnego Komitetu Nauk Pedagogicznych Polskiej Akademii Nauk, wydanie 31 $\mathrm{Z}(92 \mathrm{Z}) / 2014 \mathrm{Z}$ dnia 2 listopada $2014 \mathrm{r}$. (wersja elektroniczna przesyłana drogą mailową). $\mathrm{Na}$ relacyjny charakter edukacji oraz związane z tym wyzwania w kształceniu nauczycieli zwraca uwagę J. Michalak. Jej zdaniem, formowanie nauczycieli w kontekście ich pracy nad emocjami [odnoszącymi się do sfery relacji międzyosobowych - dopowiedzenie K.Sz.] jest problemem wciąż niedostrzeganym w obszarze szkolnictwa wyższego w Polsce, brakuje oferty oraz zajęć dydaktycznych. Zob. J. Madalińska-Michalak, R. Góralska, Kompetencje emocjonalne nauczyciela, Wolters Kluwer Polska SA, Warszawa 2012, s. 39. 
Prezentowane rozważania są formułowane w określonym kontekście teoretycznym. Za główną perspektywę badawczą przyjmuje się w artykule perspektywę edukacji rozumianej jako działanie etyczne $(\text { praxis })^{6}$ - stąd przywołanie kategorii przebaczenia jako jednego $\mathrm{z}$ wyrazów działania edukacyjnego, wokół którego koncentruje się oś rozważań. Idea rozpatrywania przebaczenia jako działania pochodzi od Hannah Arendt, sam zaś fenomen przebaczenia jest rozumiany w tekście możliwie jak najprościej i najszerzej jako przebaczenie poniesionych win i krzywd. Jeśli to, co nieprzewidywalne może rzeczywiście mieć znaczenie dla edukacji, to należy je opatrzyć kilkoma uwagami o charakterze porządkującym.

To, co nieprzewidywalne nie jest sformułowaniem jednoznacznie pozytywnym, a przynajmniej nie wywołuje takiego skojarzenia. Więcej w świadomości zbiorowej bywa przypisywane wydarzeniom wartościowanym negatywnie, jak nieszczęśliwy wypadek na drodze, wybuch czyjegoś złego humoru, niespodziewane załamanie pogody. Nieprzewidywalny może być człowiek, ale nieprzewidywalna może być też natura. Edukacji nie sposób jednak rozpatrywać z perspektywy losu, a jedynie celowej ludzkiej działalności, dlatego aspekt nieprzewidywalności związany z przypadkiem (działaniem nieintencjonalnym i nieświadomym) musi zostać pominięty.

Artykuł ma następujący układ: w pierwszej kolejności zostają przytoczone konteksty, w których przebaczenie pojawia się jako kategoria. Następnie zrekonstruowana zostaje kategoria działania oraz jedna $\mathrm{z}$ jej odmian, jaką jest przebaczenie w ujęciu Hannah Arendt ${ }^{7}$ W kolejnej części zostaje poddane analizie przebaczenie jako działanie edukacyjne. Ostatni fragment artykułu jest poświęcony omówieniu możliwości praktyki przebaczenia w szkole oraz stworzeniu instytucjonalnych ram dla jej funkcjonowania w obszarze życia codziennego.

\section{Warianty mówienia o przebaczeniu}

Przekaz wiedzy w nowocześnie zorganizowanych społecznościach odbywa się na coraz większą skalę bez konieczności fizycznego kontaktu między osobami, i coraz częściej za pośrednictwem maszyn, komputerów, na odległość, w wirtualnym świecie. Przebaczenie jako relacja, która zachodzi tylko między osobami, przywołuje humanistyczny akcent kształcenia. Choć zapropo-

6 Semantyka słowa „działanie” zawiera w sobie aktywność oraz kontekst relacji: działanie zawsze podejmowane jest w stosunku do kogoś, do czegoś; nie jest ono doznawaniem.

7 W artykule będę konsekwentnie odwoływać się do refleksji na temat przebaczenia, jakie zawarła H. Arendt w swoim dziele Kondycja ludzka, przekł. A. Łagodzka, Wydawnictwo Aletheia, Warszawa 2000. 
nowana w tekście perspektywa nie koncentruje się na analizie formalnego statusu przebaczenia, to warto przytoczyć konteksty, w których najczęściej się ono pojawia8.

Być może jednym z najbardziej oczywistych, naturalnych punktów odniesienia dla przebaczenia jest obszar wychowawczej pracy szkoły (postępowania oraz związanych z nim wartości) ${ }^{9}$. Bliskość przebaczenia i wychowania wynika, poniekąd, z socjalizacyjnej funkcji szkoły oraz z pracy nad modelowaniem określonych zachowań uczniów ${ }^{10}$. O przebaczeniu pisze się na wiele sposobów. Jest ono rozpatrywane jako złożony proces psychiczny angażujący sferę poznawczą, emocjonalną i behawioralną, który prowadzi do nowej strukturalizacji wiedzy o sobie i innych, do porządkowania sfery uczuć, wyobrażeń i sposobów reagowania ${ }^{11}$. Można je również zaliczyć do grona atrybutów kompetencji emocjonalnych rozumianych jako umiejętność adekwatnego zachowania w sytuacji szkolnej, świadomość potrzeby i skutków takiego zachowania oraz przyjęcie odpowiedzialności za skutki ${ }^{12}$. Jest wreszcie opisywane jako przejaw aktualizacji władz duchowych człowieka - działania woli na pamięć ${ }^{13}$.

Drugi, istotny kontekst przebaczenia, dzięki wpisanej w nie zdolności koncyliacyjnej, również w wymiarze instytucjonalnym, odsyła do sfery polityki. Jeśli rewersem przebaczenia jest pragnienie zemsty, to przebaczenie staje się również sprawą o publicznym znaczeniu. Lęk przed eskalacją nienawiści, przed rozprzestrzenieniem się na świecie ognisk konfliktów zbrojnych, każe stawiać pytania o możliwość życia bez przebaczenia w nieludzkim świecie. Polityczne znaczenie przebaczenia, czy raczej znaczenie przeba-

8 Nie podejmuję $\mathrm{w}$ tekście religijnego aspektu przebaczenia, który jest niewątpliwie wątkiem ważnym i zajmującym istotne miejsce $\mathrm{w}$ wielu religiach. Przyjmuję, że przebaczenie jest przede wszystkim fenomenem specyficznie „ludzkim”, dotyczącym każdego człowieka, niezależnie od jego orientacji religijnej, czy też obojętnej, a nawet wrogiej postawy wobec religii.

9 S. Kunowski, Wartości w procesie wychowania, wstęp i wybór tekstów B. Lenarczyk, Oficyna Wydawnicza Impuls, Kraków 2003, s. 46.

10 Przez socjalizacyjną funkcję edukacji rozumiem „uspołecznienie jednostki ludzkiej, czynienie jej zdolną do kontrolowania i sublimowania emocjonalności w społecznie akceptowany sposób, do stawania się członkiem społeczności ludzkiej, do rozwiązywania konfliktów środkami dyskursywnymi”. Podaję za: „edukacja” (hasło), B. Śliwerski, [w:] Encyklopedia pedagogiczna XX wieku, t. 1, A-F, T. Pilch (red.), Wydawnictwo Akademickie Żak, Warszawa 2003, s. 905-906.

${ }^{11}$ A. Król, Przebaczenie jako wartość w wychowaniu, „Roczniki Nauk Społecznych”, t. 28-29, Z. 2, s. 117 .

12 J. Madalińska-Michalak, R. Góralska, Kompetencje emocjonalne..., s. 73; 124.

13 J.A. García Cuadrado, Człowiek - byt, który zapomina, przeł. P. Roszak, [w:] U źródeł pamięci. O „zapominaniu” w historii, teologii i literaturze, P. Roszak (red.), Wydawnictwo Naukowe Uniwersytetu Mikołaja Kopernika, Toruń 2013, s. 17. 
czenia dla polityki, unaocznia potrzebę tak skonfigurowanej edukacji, która stanie się facylitatorem przemian społecznych - umiejętnością lektury dziejów historii jako historii przebaczenia oraz spojrzeniem $z$ dystansu na rzeczywistość w poszukiwaniu tego, co łączy. Można zaryzykować stwierdzenie, że obok wciąż aktualnego wyzwania prowadzenia mądrej polityki historycznej $^{14}$ (często związanego z relacją do poniesionych krzywd i strat, a zatem sytuacji potencjalnie stwarzających okazję do aktualizacji możności przebaczenia), wybrzmiewa zadanie prowadzenia edukacji „politycznej”, służącej umacnianiu postaw ułatwiających funkcjonowanie w określonej grupie społecznej, zorganizowanej wokół wspólnych zasad. Jakiś czas temu, na łamach jednej z ogólnopolskich gazet, polscy misjonarze pracujący od lat na terenach naznaczonych konfliktami między plemieniami Tutu i Hutsi, wypowiadali się na temat kulturotwórczej i edukacyjnej roli przebaczenia. Podkreślali, że tam, gdzie szybciej dochodziło do przebaczenia, tam skuteczniej postępowała odbudowa struktur lokalnych i społecznych.

Pytanie o możliwość przebaczenia wodniesieniu do popełnionych zbrodni oraz refleksja nad znaczeniem przebaczenia w polityce nie jest wątkiem nowym. Polityka jako domena słowa ciekawi badaczy, czego przykładem są chociażby analizy konstrukcji semantycznych związanych z przebaczaniem Jacquesa Derridy ${ }^{15}$, czy w polskim obszarze językowym praca Renaty Grzegorczykowej o aktach mowy o pokrewnym znaczeniu dotyczących przyznawania się do winy. Jej zdaniem, akty te mają dużą wartość, sens metafizyczny i duchowy ${ }^{16}$.

Dominantą łączącą przywołane ujęcia jest odwołanie się do perspektywy praxis, do działania. Jest to ważny aspekt przebaczenia, na który zwraca uwagę w jednej ze swoich kluczowych prac - Kondycja Ludzka Hannah Arendt $^{17}$. Prowadzony przez nią wywód jest o tyle istotny, że dzięki odnie-

14 Jest to z pewnością ciekawy temat wychowawczy - konstruowanie świadomości zbiorowej, tworzenie i utrzymywanie tożsamości narodu przez interpretację i wizję historii Polski oraz jej interakcji z innymi państwami. Wystarczy przytoczyć dla przykładu polemikę wywołaną wokół idei powstania Centrum przeciwko Wypędzeniom w Berlinie, którego inicjatorką była Erika Steinbach. Dobrym kontrapunktem może być z kolei słynny już list biskupów polskich do niemieckich z 1965 roku. Warto również podkreślić, że o ile prowadzenie polityki historycznej dotyczącej utrzymywania i spajania pamięci historycznej należy przede wszystkim do polityków i prowadzone jest głównie w obszarze działań państwowych (podejmowanych przez centralne organy władzy), o tyle prowadzenie edukacji do polityki jest zadaniem spoczywającym przede wszystkim na szczeblu lokalnym.

15 Mam na myśli jego wystąpienie zatytułowane Przebaczyć-nieprzebaczalne i nieprzedawnialne, zamieszczone później w: „Principia” 1999, t. 24-25, przkł. U. Hrehorowicz, s. 5-35.

16 R. Grzegorczykowa, O przyznawaniu się do winy i aktach pokrewnych, „Etyka” 2003, nr 34, s. 229.

${ }_{17}$ Zob. H. Arendt, Kondycja... 
sieniu do fundamentalnych pojęć i zakorzenieniu ich w filozofii praktycznej, możliwe jest przeniesienie kategorii przebaczenia jako działania o etycznym nasyceniu na grunt edukacji.

\section{Przebaczenie jako działanie}

Tekst Arendt powstał w 1958 roku, w okresie rodzących się niepokojów społecznych, a zarazem fascynacji możliwościami, jakie stwarzał rozwój technologii. Autorka, stawiając w centrum swoich zainteresowań kondycję ludzką, powracała do pytań o sprawy podstawowe, o cel, miejsce i sposób istnienia człowieka w świecie. Jej namysł nad rzeczywistością był próbą przejścia od fenomenu do fundamentu, poszukiwaniem głębszego sensu poza warstwą faktów i wydarzeń przez osadzenie ich w szerokim kontekście filozoficznym. Trzydzieści lat później, w warunkach społecznych zdominowanych przez wzrost cywilizacji przemysłowej ${ }^{18}$. Hans Jonas, niemiecki filozof o podobnej proweniencji ideowej, zwracał uwagę na ekspansję mocy człowieka, na dominację homo faber nad homo sapiens. Jego głos był kontynuacją rozważania nad problematyką relacji człowieka do przedmiotów, do wytworów swojej pracy, do świata kultury i nauki, do samego siebie, i wreszcie - do innych. Jak zatem kształtuje się istnienie człowieka w świecie?

W KondyCjI Ludzkiej, Arendt spośród trzech fundamentalnych ludzkich czynności wymienia działanie ${ }^{19}$. Jest to jedyna - jak pisze - „czynność, która zachodzi bezpośrednio między ludźmi bez pośrednictwa rzeczy czy materii i odpowiada mu ten aspekt kondycji ludzkiej, który związany jest z wielością, czyli z faktem, że ludzie, a nie człowiek, żyją na Ziemi i zamieszkują świat" ${ }^{20}$. Jedną z odmian działania jest przebaczenie, a jego charakterystykę autorka KORZENI TOTALITARYZMU przedstawia następująco:

przebaczenie jest środkiem zaradczym na nieodwracalność procesów rozpoczynających się przez działanie; służy do zniweczenia uczynków przeszłości [...]. Aktu przebaczenia nigdy nie da się przewidzieć; jest to jedyna reakcja, która dokonuje się w sposób nieoczekiwany i tym samym, mimo iż jest reakcją, zachowuje coś z pierwotnego charakteru działania. Jej wyjątkowość zawiera się również w tym, że jako jedyna reakcja po prostu nie od-działuje, ale działa na nowo i nieoczekiwanie, nieuwarunkowana przez akt, który ją wywołał, a zatem uwal-

18 Termin ten stosuję w ujęciu E. Fromma i podaję za: B. Śliwerski, Pedagogika radykalnego humanizmu, [w:] idem, Współczesne teorie i nurty wychowania, Oficyna Wydawnicza Impuls, Kraków 2004, s. 228.

19 Pozostałe dwie ludzkie czynności to praca i wytwarzanie. Jak zauważa Arendt, „są one fundamentalne, ponieważ każdy z nich odpowiada jednemu z podstawowych warunków, na jakich zostało człowiekowi dane życie na Ziemi”. Zob. H. Arendt, Kondycja..., s. 11.

${ }_{20}$ Ibidem. 
niając od jego konsekwencji zarówno tego, kto przebacza, jak i tego, komu się przebacza $^{21}$.

Ten dłuższy cytat wart jest opatrzenia kilkoma uwagami. Po pierwsze, Arendt odwołuje się do klasycznej, Arystotelesowskiej koncepcji działania ludzkiego rozumianego jako aktualizacja rozumu praktycznego. Celem takiego działania jest doskonalenie wewnętrzne podmiotu, powoływanie do istnienia czegoś, czego wcześniej nie było, czyli rodzaj twórczości wymagającej innych ludzi. Po drugie, wskazuje - choć nie wprost - na wartość działań nieprzechodnich o nieprodukcyjnym charakterze, ukierunkowanych na sferę ducha. Jest to o tyle ważne, że istotą wszelkiej kultury jest jej duchowy wymiar, co kontrastuje $\mathrm{z}$ dominującym nurtem konsumpcyjnego nastawienia na jej wytwory ${ }^{22}$. Nic dziwnego, że kulturotwórcza rola przebaczenia może zostać zakryta przez prymat logiki skuteczności oraz wymiernych, policzalnych wyników. Po trzecie, klasyfikując przebaczenie jako reakcję zupełnie nieprzewidywaną, Arendt przyczynia się do powrotu myślenia kategoriami celowości wewnętrznej wewnętrznego dynamizmu, zasady niedeterminacji właściwej bytom wolnym ${ }^{23}$. W klasycznym ujęciu filozofii, źródłem działania (actio) w człowieku jest jego rozum i wola, pojęte jako rozumne działanie ${ }^{24}$. Działanie etyczne zakłada zatem nienarzucony $\mathrm{z}$ zewnątrz status oraz zmianę jakościową $\mathrm{w}$ osobie $\mathrm{w}$ zakresie jej wewnętrznych właściwości. Przedstawione wątki pozwalają na zestawienie przebaczenia jako działania $\mathrm{z}$ edukacją jako działaniem etycznym.

\section{Edukacja jako działanie etyczne}

Wielość definicji edukacji oraz prób jest typologizacji odpowiada mnogości przyjmowanych przez badaczy perspektyw. Najbliższe pracy jest ujęcie edukacji podkreślające aktywność podmiotów biorących udział w procesie kształcenia. Takie stanowisko zajmuje gdański pedagog Piotr Zamojski. W tekście

$21 \quad$ Ibidem, s. 269.

22 S. Kowalczyk, Filozofia kultury. Próba personalistycznego ujęcia problematyki, Redakcja Wydawnictw Katolickiego Uniwersytetu Lubelskiego, Lublin 1996, s. 95, 98.

23 Trzeba uściślić, że celowość rozumiana najszerzej jest powszechną zasadą bytowania rzeczy i motywem wszelkiego działania (świadomego i nieświadomego). Rozumienie celowości podaję za: A. Maryniarczyk, Zeszyty z metafizyki IV. Racjonalność i celowość świata osób i rzeczy, SITA, Lublin 2000, s. 85-86. W tekście konsekwentnie zawężam to pojęcie do celowości właściwej bytom świadomym, które wyznaczają swoje cele w sposób wolny, nienarzucony z zewnątrz.

24 Hasło „Actio-Passio”, oprac. A. Maryniarczyk, [w:] Powszechna encyklopedia filozofii A-B, A. Maryniarczyk (red.), Polskie Towarzystwo Tomasza z Akwinu, Lublin 2000, s. 596o. Również Tadeusz Kotarbiński analizując pojęcie czynu, ujmował je w kategoriach zachowania świadomie celowego, wyraźnie umyślnego. Zob. idem, Czyn, wydanie drugie przejrzane i poprawione, Polskie Wydawnictwo Filozoficzne, Lwów 1937, s. 11. 
dotyczącym miejsca normatywności w dyskursie pedagogiki stwierdza, że działanie edukacyjne jest działaniem etycznym, czyli takim, które zachodzi między ludźmi, a nie między człowiekiem a przedmiotem ${ }^{25}$. Postuluje:

jeśli chcemy rozpoznać działanie edukacyjne jako kwestię etyczną, trzeba je przede wszystkim rozpatrzeć jako praktykę, a nie jako technikę. Wówczas musi ono być pojmowane jako niealgorytmiczne, intersubiektywne działanie, które będąc dynamiczną inter-akcją, tworzy niemożliwe do zaplanowania i przewidzenia sytuacje ${ }^{26}$.

Poza oczywistą, referencyjną aluzją do dzieła Arendt oraz wyczuwalnym pokrewieństwem ideowym między przywołanymi autorami, na uwagę zasługuje jeszcze jeden element. Wyjątkowość etycznie rozpatrywanych działań edukacyjnych zawiera się również w tym, że są to relacje możliwe do zaistnienia tylko między bytami ożywionymi oraz racjonalnymi. Warto zauważyć, że tak przeprowadzona argumentacja stawia się w opozycji do posthumanistycznej filozofii.

Istota posthumanizmu zawiera się w negacji wyjątkowego miejsca człowieka w świecie i odmienności jego zachowań wobec innych form życia. Właściwe tej postawie jest poszukiwanie punktów zacierania się granic między działaniem ludzi, maszyn i zwierząt. Wraz z porzuceniem klasycznej hierarchii bytów, również (hierarchiczny) podział na naturę i kulturę czy ludzi i zwierzęta - jak głoszą zwolennicy tego podejścia - powinien zostać zniesiony ${ }^{27}$. Dekonstrukcja różnicy w sposobie istnienia bytów ożywionych przyczynia się do deklasyfikacji szczególnego charakteru działania w przypadku ludzi. Stąd,

intelektualny mit posthumanizmu angażuje się wkształtowanie nieantropocentrycznych postaw i promuje wizję człowieka zdecentrowanego. Człowiek jest tylko jednym $\mathrm{z}$ wielu biologicznych organizmów ulokowanych w sieci witalnych współzależności z nie-ludzkimi formami życia i technologiami ${ }^{28}$.

To twierdzenie, odniesione do kategorii działania, znaczenie zawęża jego zakres, gdyż trudno przypisać bytom nieracjonalnym zdolność do immanencji czy autorefleksji. Choć między świadomością a wolnością przebiega cienka granica, nie są to pojęcia jednoznaczne. Świadomość może również zostać

25 P. Zamojski, Miejsce normatywności w dyskursie pedagogiki: ku pojmowaniu działania edukacyjnego jako kwestii etycznej, [w:] Etyka i profesjonalizm w zawodzie nauczyciela, J. Michalak (red.), Wydawnictwo Uniwersytetu Łódzkiego, Łódź 2010, s. 335.

26 Ibidem, s. 336 .

${ }_{27}$ M. Bakke, Bio-transfiguracje. Sztuka i estetyka posthumanizmu, Wydawnictwo Naukowe UAM, Poznań 2010, s. 8, 21.

${ }_{28}$ Ibidem. 
sztucznie wzbudzona; wolność należy tylko do człowieka. Pytanie o to, czy i w jaki sposób przebaczenie jako osobista relacja, działanie między osobami, może się urzeczywistnić w przestrzeni szkoły, jest tylko pozornie pytaniem wyłącznie praktycznym. Odpowiedź na nie wiąże się z przyjęciem postawy określonej ideowo.

\section{Praktyka przebaczenia w szkole}

$\mathrm{Na}$ fenomen szkoły składają się dwa wymiary: instytucjonalny (formalny aspekt jej funkcjonowania) oraz praktyczny (działania zachodzące w szkole). Pytanie o praktykę przebaczenia w szkole, to pytanie o możliwość instytucjonalizacji tego, co osobiste, o miejsce przebaczenia w szkole jako instytucji, która rządzi się swoimi prawami i w której dochodzi do nieustannych, czasem znaczących, interakcji między osobami, wykraczających daleko poza sferę czysto poznawczą. Arendt zaznacza wybitnie osobisty, choć niekoniecznie indywidualny czy prywatny charakter przebaczenia i relacji, jaką ono ustanawia $^{29}$. Również dla Zamojskiego działania edukacyjne odnoszą się do całości społecznej, dla której mogą mieć niszczący lub rozwojowo-twórczy (emancypujący) sens ${ }^{30}$.

W nurt prowadzonych rozważań dotyczących relacji między sferą prywatną (osobistą) a instytucjonalną wpisują się również uwagi znanego filozofa polityki. Zbigniew Stawrowski dokonał niedawno analizy jednego $\mathrm{z}$ fenomenów relacji międzyludzkich, jakim jest solidarnośśc ${ }^{31}$. Podobny do przebaczenia, niewymuszony oraz relacyjny charakter solidarności pozwala na wykorzystanie przytoczonych przez badacza uwag. W odniesieniu do ulokowania tego fenomenu w przestrzeni państwa, Stawrowski zauważa, że dobrze zorganizowane państwo musi być sprawiedliwe, ale - wbrew potocznemu mniemaniu - nie tylko nie powinno, ale wręcz nie może być solidarne. Nie może, ponieważ

solidarności jako zbudowanej na fundamencie miłości nie da się rozbudzić ani urzeczywistnić środkami przymusu, których używanie należy właśnie do istoty państwa. Rolą państwa jest natomiast tworzenie w państwie instytucjonalno-prawnej przestrzeni, która może wspierać solidarne zachowania ${ }^{32}$.

Z. Stawrowski, Przestrzeń dla Samarytanina, „Plus-Minus”, dodatek do „Rzeczpospolitej” 2014, 31 października - 2 listopada, s. 29-30.

32 Precyzował: [...] „praca nad jak najbardziej przyjaznym kształtem instytucji, w ramach których toczy się nasze życie, jest szczególnym zadaniem i wyzwaniem. Właściwie pojęta polityka, bo o niej tutaj mowa, może być rozumiana jako pomoc - w sposób pośredni poprzez tworzenie właściwych rozwiązań prawnych - ludziom w potrzebie (...), może być 
Analogicznie, w ramach postulatów dotyczących tworzenia kultury szkoły może się znaleźć postulat dotyczący postawy przebaczenia.

Instytucjonalna kategoryzacja przebaczenia prowadzi do ciekawych zestawień. Sytuując się poza obszarem normy, tego, co obowiązujące, przebaczenie może być rozpatrywane jako „destabilizacja” szkolnej normy, utartych schematów działania. Być może, paradoksalnie właśnie w tym czynniku ujawnia się jej wkład w humanizację edukacji, możliwość odkrycia na nowo sfery ducha, zaznaczenie wartości tego, co niepowtarzalne. Oczywiście, nie sposób traktować „destabilizacyjnej” właściwości przebaczenia w sposób dosłowny i ciągły: znaczy ono tyle, co niewystarczalność kierowania się zasadami prawa i normami w jakiejkolwiek zorganizowanej społeczności.

Przebaczenie transponowane na grunt szkoły ukazuje jeszcze jeden wspólny element - zakorzenienie w umownej rzeczywistości, działanie tak, jakby nic się nie stało. Umowność sytuacji edukacyjnej (określona grupa uczniów spotyka się, żeby uczyć się w jednym miejscu) zbiega się z umownością sytuacji związanej z przebaczeniem (postępowanie tak, jakby nic się nie wydarzyło). Potoczne doświadczenie oraz filozoficzny ogląd rzeczywistości zbiegają się w jednym punkcie:

całkowite zapomnienie o darowanych krzywdach wydaje się jednak niemożliwe, ponieważ spontaniczna pamięć o doznanym złu pojawia się w nas w sposób nie do uniknięcia: to, co nie jest dobrowolne, nie może być wymagane, gdyż człowiek nie jest absolutnym właścicielem swoich wspomnień. Jeśli przebaczenie nie może wymagać zapomnienia (gdyż pamięć nasycona uczuciowością spontanicznie przedstawia doznane krzywdy), to jednak można oczekiwać, że przebaczywszy wola będzie tak wpływać na pamięć, aby nie uobecniała doznanego zła, choć nie zawsze to się uda. Nie można wymagać od ludzkiej wolności, aby zapomniała to, co niezapomniane, ale za to może być skłaniana do przebaczenia, to znaczy do postępowania „jak gdyby” nie zdarzyła się krzywda, którą popełniono ${ }^{33}$.

Polityczny, a nie absolutny charakter zależności między uczuciami, rozumem a wolą stanowi ważny wkład w świadomość rozwijania się procesów międzyludzkich, w kierowanie uczuciami. Bez refleksji nad swoim zachowaniem oraz postępowaniem innych osób, etyczna postawa zostaje zastąpiona nieracjonalnymi praktykami. Frustracja, lęk, niezadowolenie $\mathrm{z}$ niespodziewanego obrotu spraw ${ }^{34}$, które można rozwiązać uznaniem swojej winy, albo

również bezpośrednio doświadczana przez tak umotywowanych polityków jako solidarne współdziałanie. Polityka realizowana w duchu roztropnej troski o dobro wspólne oba te wymiary - miłosierdzia i solidarności - jakoś w sobie zawiera”. Zob. Z. Stawrowski, Przestrzeń..., s. 30 .

33 J.A. García Cuadrado, Człowiek..., s. 33.

34 Jakże często czynnik nieprzewidywalności znajduje się po stronie uczniów, ich przeżyć, tego, co doświadczyli danego dnia, co zobaczyli, z kim się spotkali, co ktoś im powiedział... 
aktem przebaczenia, przynależą do porządku reakcji. Potrzeba jednak świadomości, aby te reakcje stały się, w słowach Arendt, nowym działaniem, a nie tylko od-działywaniem.

Choć przebaczenie nie może być zagwarantowane, to refleksja nad własną winą oraz możliwością przebaczenia staje się bliższa poziomowi etycznemu. Do istoty nabywania wiedzy moralnej należy doświadczenie, ale i świadomość tego, co się zrobiło. Jak pisał Leszek Kołakowski:

przyswajamy sobie wiedzę moralną nie przez to, że ktoś nas przekona, że Kant lub Husserl, lub Platon mieli rację, ale przez to, że jesteśmy zdolni do poczucia winy i rzeczywiście go doświadczamy, gdy łamiemy reguły, o których wiemy, że są prawomocne ${ }^{35}$.

\section{Podobne stanowisko reprezentuje Robert Spaemann. Jego zdaniem}

instytucja nie może [...] w ścisłym sensie przebaczać. Może tylko tak kształtować swoje procedury, aby wskazywały one na możliwość przebaczenia, to znaczy pozwalały i umożliwiały człowiekowi zdystansowanie się do swoich czynów $w^{36}$.

Refleksyjna praktyka zdobyta w instytucji pozwala na założenie, że uczniowie, nauczyciele, dyrekcja, zdobywszy dzięki przebaczeniu doświadczenie „Czynnika” ludzkiego w szkole jako instytucji, sami staną się w innych kontekstach instytucjonalnych inicjatorami zmian społecznych ${ }^{37}$, wyrażających się w etycznych działaniach opartych na zasadzie niedeterminacji.

Niewątpliwie, szkoła pozostaje nadal jednym z głównych miejsc związanych z szeroko pojętą codziennością, zaś współczesna dyskusja wokół problematyki etycznej toczy się wokół potrzeby powrotu do spraw związanych z życiem codziennym oraz podstawowymi intuicjami moralnymi. Chodzi o obronę etyki przed teoretycznymi dywagacjami niemającymi przełożenia na zwyczajne życie, które dodatkowo utwierdzają status tej nauki jako odrealnionej, abstrakcyjnej i nieprzydatnej do niczego ${ }^{38}$. Zwyczajność sytuacji wydarzających się w szkole podkreśla znaczenie doświadczenia jako praktyki

35 L. Kołakowski, O tym, co dobre i prawdziwe, [w:] idem, Mini wykłady o maxi sprawach, seria druga, Wydawnictwo Znak, Kraków 1999, s. 88.

36 R. Spaemann, Osoby. O różnicy między czymś a kimś, przekł. J. Merecki SDS, Oficyna Naukowa, Warszawa 2001, s. 287.

37 Termin „zmiana społeczna” stosuję za M.J. Szymańskim. Zob. idem, Socjologia edukacji. Zarys problematyki, Oficyna Wydawnicza Impuls, Kraków 2013, s. 90.

38 Taki zamysł - jako postulat i praktyka pewnego działania zgłosili naukowcy z UMK. Napisana przez nich książeczka jest - jak deklarują - „próbą reartykulacji, renowacji i rekonfiguracji znanych sprawności moralnych, choć nieco przykurzonych i zapomnianych". Zob. P. Domeracki, M. Jaranowski. M.T. Zdrenka, Sześć cnót mniejszych, Wydawnictwo Naukowe Uniwersytetu Mikołaja Kopernika, Toruń 2012, s. 12-13. 
osadzonej w kontekście życia codziennego. Przykłady narzucają się same: nauczyciele mogą wybaczyć uczniom niewybredną uwagę, „głupawkę” na lekcji, a uczniowie nauczycielom złośliwe komentarze, nieprzygotowanie do zajęć, zły humor i utratę cierpliwości. Wiele sytuacji zapalnych - okazji do przebaczenia - zdarza się również w gronie pedagogicznym: drobne złośliwości, obgadywanie kogoś za czyimiś plecami, niezwrócenie na czas potrzebnego magnetofonu, bez którego inny nauczyciel nie mógł przeprowadzić lekcji... Można zatem bez przesady stwierdzić, że przebaczenie zarówno w teoretycznym, jak i praktycznym wymiarze, pozostaje wciąż nośną i aktualną kategorią dla pedagogicznej refleksji.

\section{Zakończenie}

Podjęcie w artykule problematyki przebaczenia jako działania edukacyjnego, mieszczącego się w obszarze nieprzewidywalności, miało na celu zrównoważenie wizji edukacji budowanej na podstawie idei rynku i podporządkowanej prawom ekonomii. Jako relacja etyczna między osobami, ta kategoria podkreśla wartość działań praktycznych, a nie tylko teoretycznych czy poznawczych, i stanowi wyzwanie dla kształcenia nauczycieli. Można postawić tezę, że edukacja w znaczeniu działania edukacyjnego, zawieszona między neoliberalnymi a posthumanitarnymi orientacjami, potrzebuje przede wszystkim antropocentrycznego zwrotu i podkreślenia jej relacyjnego charakteru oraz celowości wewnętrznej właściwej osobom. Jak pisał Józef Tischner w odniesieniu do idei regulujących relacje międzyludzkie: „nie wszystko musi być zorganizowane. Nie wszystko może być zorganizowane. Człowiek musi mieć jakieś pole wolności i swobody. [...]. Wolność jest zawsze związana z jakimś stopniem nieprzewidywalności”39.

Wydaje się wreszcie, że to, co nieprzewidywalne może stać się wartością tylko z perspektywy etycznej. Jakiś czas temu Etienne Wenger wprowadził termin „wspólnot praktyków”^^ na określenie grup objętych wspólnymi wyzwaniami i wartościami, skupionych na pozyskiwaniu wiedzy, uczeniu się. Choć w opisie tej kategorii na pierwszy plan wysuwa się celowość poznawcza, to znajduje ona zastosowanie również w omawianym tutaj kontekście. W kształtowaniu kultury edukacji na wszystkich etapach kształcenia, w tworzeniu „wspólnot praktyków” warto postulować o miejsce dla praktyki prze-

39 J. Tischner, Etyka solidarności, Wydawnictwo Znak, Kraków 1981, s. 49.

40 Termin oraz rozumienie pojęcia „wspólnota praktyków” podaję za: J. Michalak, Studencka praktyka naukowo-badawcza. Zagadnienia etyczne, [w:] Etyka i profesjonalizm w zawodzie nauczyciela, J. Michalak (red.), Redakcja Naukowa Uniwersytetu Łódzkiego, Łódź 2010, s. 428. 
baczenia jako konstytutywnego doświadczenia dla wszelkich relacji międzyosobowych, które zwykle mają charakter etyczny ${ }^{41}$.

\section{BIBLIOGRAFIA}

Arendt H., Kondycja ludzka, przekł. A. Łagodzka, Wydawnictwo Aletheia, Warszawa 2000.

Bakke M., Bio-transfiguracje. Sztuka i estetyka posthumanizmu, Wydawnictwo Naukowe Uniwersytetu Adama Mickiewicza, Poznań 2010.

Derrida J., Przebaczyć-nieprzebaczalne i nieprzedawnialne, przekł. U. Hrehorowicz, „Principia” 1999, t. 24-25.

Domeracki P., Jaranowski M., Zdrenka M.T, Sześć cnót mniejszych, Wydawnictwo Naukowe Uniwersytetu Mikołaja Kopernika, Toruń 2012.

Encyklopedia pedagogiczna XX wieku, t. 1, A-F, T. Pilch (red.), Wydawnictwo Akademickie „Żak”, Warszawa 2003.

García Cuadrado J.A., Człowiek - byt, który zapomina, przekł. P. Roszak, [w:] Uźródeł pamięci. O „zapominaniu” w historii, teologii i literaturze, P. Roszak (red.), Wydawnictwo Naukowe Uniwersytetu Mikołaja Kopernika, Toruń 2013.

Grzegorczykowa R., O przyznawaniu się do winy i aktach pokrewnych, „Etyka” 2003, nr 34.

Jonas H., Zasada odpowiedzialności. Etyka dla cywilizacji technologicznej, przekł. M. Klimowicz, Wydawnictwo Platan, Kraków 1996.

Kaszyński K., W poszukiwaniu wartości, [w:] Humanizm, prakseologia, pedagogika, Z. Wołk (red.), Wydawnictwo Naukowe Wyższej Szkoły Pedagogicznej im. Tadeusza Kotarbińskiego, Zielona Góra 1998.

Kołakowski L., O tym, co dobre i prawdziwe, [w:] idem, Mini wykłady o maxi sprawach, seria druga, Wydawnictwo Znak, Kraków 1999.

Kotarbiński T., Czyn, wydanie drugie przejrzane i poprawione, Polskie Wydawnictwo Filozoficzne, Lwów 1937.

Kowalczyk S., Filozofia kultury. Próba personalistycznego ujęcia problematyki, Redakcja Wydawnictw Katolickiego Uniwersytetu Lubelskiego, Lublin 1996.

Król A., Przebaczenie jako wartość w wychowaniu, „Roczniki Nauk Społecznych” 200o-2001, t. 28-29, z. 2.

Kunowski S., Podstawy współczesnej pedagogiki, Wydawnictwo Salezjańskie, Warszawa 1993.

Kunowski S., Wartości w procesie wychowania, wstęp i wybór tekstów B. Lenarczyk, Oficyna Wydawnicza Impuls, Kraków 2003.

Madalińska-Michalak J., Góralska R., Kompetencje emocjonalne nauczyciela, Wolters Kluwer Polska SA, Warszawa 2012.

Maryniarczyk A., Zeszyty z metafizyki IV. Racjonalność i celowość świata osób i rzeczy, SITA, Lublin 2000.

Michalak J., Studencka praktyka naukowo-badawcza. Zagadnienia etyczne, [w:] Etyka i profesjonalizm $w$ zawodzie nauczyciela, J. Michalak (red.), Redakcja Naukowa Uniwersytetu Łódzkiego, Łódź 2010.

Powszechna encyklopedia filozofii A-B, A. Maryniarczyk (red.), Polskie Towarzystwo Tomasza z Akwinu, Lublin 2000.

Spaemann R., Osoby. O różnicy między czymś a kimś, przekł. J. Merecki SDS, Oficyna Naukowa, Warszawa 2001.

Stawrowski Z., Przestrzeń dla Samarytanina, „Plus-Minus”, dodatek do „Rzeczpospolitej” 2014, 31 października - 2 listopada.

${ }^{41} \quad$ Serdecznie dziękuję Paniom: dr hab. Agnieszce Nogal z Instytutu Filozofii UW oraz dr Annie Dąbrowskiej z Wydziału Pedagogicznego UW za lekturę pierwotnej wersji tekstu oraz cenne uwagi. 
Śliwerski B., Komu służą rankingi oświatowe?, [w:] Przestrzeń edukacyjna - dylematy, doświadczenia i oczekiwania społeczne, M. Kowalski, A. Pawlak, A. Famuła-Jurczak (red.), Oficyna Wydawnicza Impuls, Kraków 2010.

Śliwerski B., Pedagogika radykalnego humanizmu, [w:] idem, Współczesne teorie i nurty wychowania, Oficyna Wydawnicza Impuls, Kraków 2004.

Szymański M.J., Socjologia edukacji. Zarys problematyki, Oficyna Wydawnicza Impuls, Kraków 2013.

Tischner J., Etyka solidarności, Wydawnictwo Znak, Kraków 1981.

Zamojski P., Miejsce normatywności $w$ dyskursie pedagogiki: ku pojmowaniu działania edukacyjnego jako kwestii etycznej, [w:] Etyka i profesjonalizm w zawodzie nauczyciela, J. Michalak (red.), Wydawnictwo Uniwersytetu Łódzkiego, Łódź 2010.

\section{SUMMARY}

\section{Forgiveness as an action.}

The meaning of the unpredictable for education

The aim of the paper is to draw attention to the issue of forgiveness in terms of its unpredictability (non-system) and to emphasize the importance of this category for education and teacher training. The text presents also the possibility of practical application of this category to the school, on the basis of the concept of forgiveness, used by Hannah Arendt.

KEYWORDS: forgiveness, educational action, unpredictability, school as an institution, humanisitic orientation of education, teacher training. 